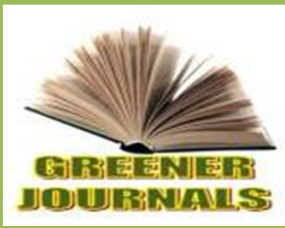

\title{
Farmers' Participation in Agroforestry Practices in Taraba State, Nigeria: An Analysis of Benefits
}

\section{Edward Adyondor Karshie (PhD) ${ }^{\star}$, Oluwatosin Victor Ajayi, Philip Kwakwah Gideon, Joel Bulus, Naorti Boniface Mtomga}

\author{
Department of Forestry, College of Agriculture, Jalingo, Taraba State, Nigeria.
}

\section{ARTICLE INFO}

Article No.: 092417139

DOI: 10.15580/GJAS.2017.8.092417139

Submitted: $24 / 09 / 2017$

Accepted: 04/10/2017

Published: 14/10/2017

${ }^{*}$ Corresponding Author

Edward Adyondor Karshie

E-mail: edwardkarshie

@gmail.com

Keywords:

Agroforestry, benefits derived, farmers' participation, Taraba State
Proximate and mineral analysis, carbohydrate composition, functional properties and anti-nutritional factors of Tamarindus indica (L.) and Ziziphus spina christi seed and fruit were determined using standard methods. Ziziphus spina christi seed was found to be rich in protein (24.07\%) than Tamarindus indica pulp (7.64\%) and Ziziphus spina christi fruit (8.23\%). The crude fat content of all the samples, Tamarindus indica pulp (1.03\%), Ziziphus spina christi fruit (1.94\%), Ziziphus spina christi seed (1.24\%) were low. High carbohydrate values, $56.00 \%, 58.02 \%$ and $35.25 \%$ were obtained for Tamarindus indica pulp and Ziziphus spina christi fruit and seed respectively. Meanwhile, the functional properties of Ziziphus spina christi fruit was relatively higher than the seed and Tamarindus indica pulp. Values obtained for dextrose, fructose, maltose and other sugars showed that they all contain an appreciable amount of sugar. The anti-nutritional factors depicted that they all contained low amount of oxalate, tannic acid, phytin phosphorus except the phytic acid, 5.74, 6.56, and 8.24 (mg/100g for Tamarindus indica pulp and Ziziphus spina christi fruit and seed respectively. The mineral analysis showed that the $\mathrm{Ca} \mathrm{Mg}$, and Fe contents of these samples were relatively high with Ziziphus spina christi seed having the highest value of $\mathrm{Fe}$ (58.53 $\mathrm{mg} / 100 \mathrm{~g}$ ) compared with Tamarindus indica pulp (27.36 mg/100g) Ziziphus spina christi $(39.96 \mathrm{mg} / 100 \mathrm{~g})$. The results generally indicated that T.indica pulp and Ziziphus spina christi fruit and seed were good sources of protein, mineral and energy foods and can be used in food formulation. 


\section{INTRODUCTION}

Agroforestry system practices offers solution to land shortage, poverty, food security and environmental degradation. Leakey (2006) defined agroforestry as a dynamic, ecologically based natural resources management system that, through the integration of trees on farms and in the agricultural landscape, diversifies for increased social, economic and environmental benefits for land- users at all levels. Similarly, Nair (2008) describes agroforestry as a form of land use that successfully satisfies the needs of the crop farmer, forester and livestock farmer. King (2007) describes agroforestry as a sustainable land management system which constitutes the overall yield of the land combines the production of crops (including tree crops) and forest plants and/or animals simultaneously or sequentially, on the same unit of land and applies management practices that are compatible with the cultural practices of the local population. Nair (2008) recognized about eighteen different Agroforestry practices although each has an infinite number of variations. Some of the widely known exotic Agroforestry practices include the following: Agrosilviculture, silvopastoral, agro-silvopastoral, agro-pisciculture, aquasilvicultural, apiculture and sericulture. These Agroforestry practices involve various combinations of two or three of the following enterprises namely: crops, woody plant, animal rearing, fish farming, bee-keeping, silkworm farming. However, taungya, alley cropping and homestead gardens are example of indigenous practices.

Agroforestry techniques offer considerable benefits for long term agricultural sustainability. Trees and shrubs have an important ecological and economic role in farming systems. Agroforestry is useful in the following ways: cash income, providing additional or offseason employment, enabling the sale of tree products, providing investments such as orchards, tree products, agro-business and long-term supply of materials for the production of crafts, protecting soil from erosion, increasing nutrients in poor soils, providing cheaper and more accessible fuelwood, providing cheaper building materials, protecting animals, crops and humans from wind and sun, providing fencing to protect crops from livestock and wild animals (Ajayi, 2015).

Agroforestry as a way of instituting sustainable agricultural development in Nigeria was introduced a few years ago. This is to combat the various environmental problems observable with the purpose of assisting farmers to maintain the fertility of their soils, ensure diversification of crop, wood and timber species per unit area and to stabilize, improve and conserve farmers' environment. Participation of these farmers therefore becomes indispensable since it determines the success of the program. Akinbile, et al (2007) submitted that the participatory approach to any intervention programme designed for the development of an area of interest has widely been accepted as a best way to ensure meaningful and sustainable benefits.

Farmer participation in Agroforestry practices is therefore, essentially important for the desired benefits of the practices to farmers and the communities as a whole. Although the people of Taraba State, Nigerian for years have been practicing agroforestry but the level of participation in various agroforestry activities by the farmers in the communities have not been examined. Therefore, the study examined if benefits derived have any influence on farmers level of participation in Agroforestry practices in Taraba State as a study area.

The objective of this study is to examine the benefits derived on farmers' participation in Agroforestry practices in Taraba State, Nigeria.

$>$ Identify the agroforestry system practices in Taraba State, Nigeria

$>$ Identify the benefits derived by participating in agroforestry practices and;

$>$ Identify the major constraints confronting farmers in the sustainability of agroforestry practices.

The following null hypotheses were tested:

$>$ There is no significant relationship between farmers' participation in agroforestry practices and the benefits derived.

$>$ There is no significant relationship between farmers' participation in agroforestry practices and constraints.

\section{MATERIALS AND METHODS}

The study area was Taraba State, Nigeria. Taraba State lies between Latitude $6.5^{\circ}$ and $8.5^{\circ}$ North of the Equator and longitude $9.0^{\circ}$ and $14.0^{\circ}$ East Meridian. The State is bounded to the North and Northeast by Gombe and Adamawa States, to the West and Southwest by Plateau and Benue States and to the South by the Republic of Cameroon as shown in figure 1 . The choice of this area was premised on the fact that Agroforestry practice among the farmers has already been introduced by the Taraba State Agricultural Development Programme (TSADP). The state ADP has done this with the general objective of combating many of the environmental problems facing farmers in the state.

A multistage sampling technique was used in this study. The three agro-ecological zones of state ADP consist of sixteen local governments areas. In stage one, three out of the six local governments $(50 \%$ representation) from Zone one (Zing Zone) and two out of the five local governments ( $40 \%$ representation) from zone two (Wukari Zone) and two out of the five local governments (40\% representation) from zone three (Gembu Zone) were randomly selected. In the second 
stage, from the seven selected local governments, three out of the ten circles (30\% representation) in each local government were also randomly selected. This gave a total of 21 circles. In the third stage, twenty farmers per circle were randomly selected which gives a total of 420 farmers used in this study.

A validated structured questionnaire was the basic instrument used in this study. The questionnaire was utilized to obtain primary data and secondary data from Taraba State Agricultural Development Programme, and Journals publications. The primary data were information on farmers' benefits derived from agroforestry practices, constraints and level of their participation in agroforestry practices and suggestions of possible ways of improving the situation. The instrument used for data collection was validated for content appropriateness and it was also subjected to pre-test which yielded a reliability of 0.76 using Pearson moment correlation coefficient. The interview schedules were through trained enumerators.

Descriptive statistic of frequency count and percentage were used to explain the data while inferential statistics of Pearson product moment correlation was employed to test the hypothesis

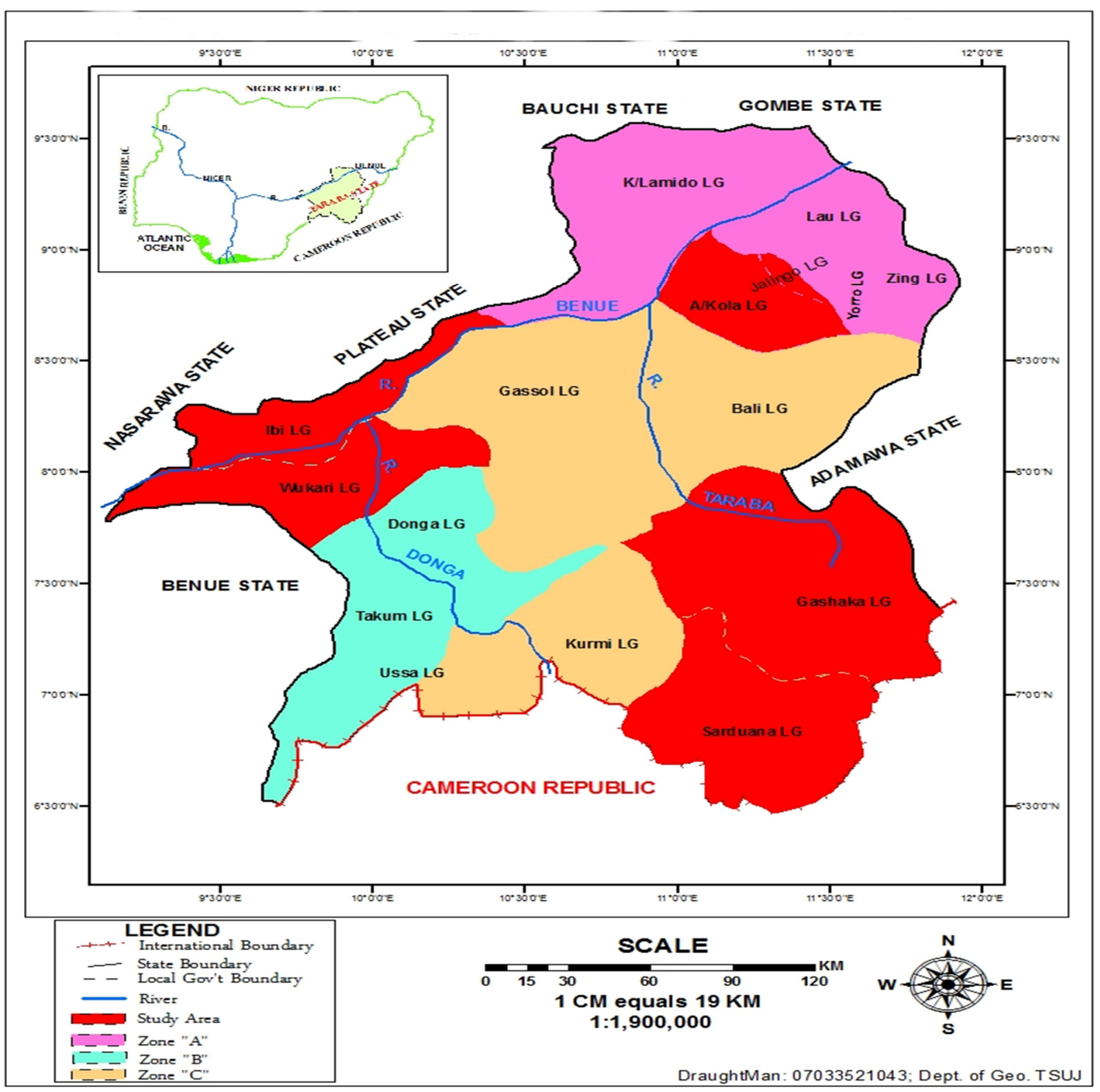

Fig 1: Map of Taraba State showing the study area 


\section{RESULTS AND DISCUSSION}

Table 1 revealed the various preferred agroforestry system practices in Taraba State, Nigeria including the tree, crop and animal species. Agrosilviculture, silvopastoral, agro-silvopastoral, agro-pisciculture, aquasilvicultural, apiculture and sericulture, silkworm farming, taungya, alley cropping and homestead gardens are the major preferred agroforestry practices in the study area. Table 2 also revealed the perceived benefits derived from Agroforestry practices as given by the respondents in order of ranking. Increase in income was ranked 1st as the most benefit with a mean score of 2.50. This is in line with Adelabu (2010) who found that agroforestry allows good production and add to per capita income of the farmers. Crops produced by the farmers were not only consumed by the family, but were also sold for cash thus serving as means of meeting some family needs. Similarly, the products of the tree components of agroforestry are also cash oriented. Furthermore, the proceeds from the livestock of agroforestry farmers had also generated additional income to the farmers.

Provision of forest materials for building was ranked 2nd. Farmers used tree component of agroforestry during the construction of their houses, this also goes a long way in reducing cost of building incurred by the farmers. Availability of more source of revenue was ranked 3rd, there is greater benefit and reduction in economic risks when systems produce multiple products as explained earlier. This provides a guaranteed source of income to the farmers. Increased crop yield was ranked 4th. Respondents claimed participation in agroforestry had afforded them benefit of enjoying increased yield and variety of crops. Improvement in the management of soil fertility through application of livestock dung waste as manure and conservation of soil nutrient by the same nitrogen-fixing trees and shrubs has really contributed to increase in crop yield realized by the farmers. The 5th benefit was extraction of tree leaves and barks for medicinal purposes. The extracted tree barks and leaves are usually boiled, and the liquid is consumed orally, for the treatment of a wide range of illnesses.

The result in table 3 indicates that the major challenges faced by respondents include high cost of labour (25.95\%), finance/capital (24.52\%), livestock grazing $(21.43 \%)$ and insufficiency of planting species $(11.67 \%)$. The result in table 4 reveals that $r=0.310, P=$ 0.000 . This implies the null hypothesis that says, there is no significant relationship between benefits derived and farmers' participation in agroforestry practice is rejected. This implies that, benefit derived had a strong positive correlation with farmer level of participation in Agroforestry practices. That is, $9.61 \%\left(0.31^{2}\right)$ of the variation in farmers' participation is explained by benefit derived. Meanwhile, at $r=0.810, P=0.000$. This implies the null hypothesis that says, there is no significant relationship between constraints and farmers' participation in agroforestry practice is rejected. This implies that constraints significantly predicted farmer participation in Agroforestry practices. The finding agrees with Sangeetha, et al (2015) and Karshie, et al (2017) who found that lack of seedlings was the most critical constraint faced by famers in adoption of agroforestry species with 3.62 mean rank values.

Table 1: Components of Agroforestry Practices in Taraba State, Nigeria.

\begin{tabular}{|c|c|c|c|c|}
\hline Agroforestry Systems & Common Practices & Tree species combined & Crops combined & Animals \\
\hline \multirow[t]{2}{*}{ Agrosilviculture } & Alley cropping and & $\begin{array}{l}\text { Gliricidia sepium } \\
\text { Leucaena leucacephala } \\
\text { Calliandra calathyrsus } \\
\text { Sesbania grandiflora } \\
\text { Athornea cordifolia }\end{array}$ & $\begin{array}{l}\text { Melon } \\
\text { Soybean } \\
\text { Beans } \\
\text { Sorghum } \\
\text { Maize }\end{array}$ & $\begin{array}{l}\text { Cattle } \\
\text { Goat } \\
\text { Sheep }\end{array}$ \\
\hline & Wind break & $\begin{array}{l}\text { Azadirachta indica } \\
\text { Eucalyptus camadulensis } \\
\text { Acacia auriculaifornis } \\
\text { Dalbergia sisso } \\
\text { Senna siamea }\end{array}$ & $\begin{array}{l}\text { Maize } \\
\text { Sorghum } \\
\text { Millet }\end{array}$ & $\begin{array}{l}\text { Cattle } \\
\text { Goats } \\
\text { Sheep }\end{array}$ \\
\hline Silvipastoral & $\begin{array}{l}\text { Integrated trees- } \\
\text { pasture }\end{array}$ & $\begin{array}{l}\text { Prosopis cineraria } \\
\text { Anthronantha macrophylla } \\
\text { Acacia nilotica } \\
\text { Moringa oleifera } \\
\text { Gliricidia sepium } \\
\text { Albiziza lebbek }\end{array}$ & $\begin{array}{l}\text { Soybeans } \\
\text { Beans } \\
\text { Sorghum } \\
\text { Maize }\end{array}$ & $\begin{array}{l}\text { Cattle } \\
\text { Sheep } \\
\text { Goats }\end{array}$ \\
\hline Agro pastoral & Alley farming & $\begin{array}{l}\text { Acacia nilotica } \\
\text { Alebizzia procera } \\
\text { Prosopis cineraria } \\
\text { Leucaena leucocephala }\end{array}$ & $\begin{array}{l}\text { Soybeans } \\
\text { Beans } \\
\text { Sorghum } \\
\text { Maize }\end{array}$ & $\begin{array}{l}\text { Sheep } \\
\text { Goats } \\
\text { Cattle }\end{array}$ \\
\hline
\end{tabular}


Terminalia arjuna

\begin{tabular}{|c|c|c|c|c|}
\hline Aquasilviculture & $\begin{array}{l}\text { Tree, snail and fish } \\
\text { farming }\end{array}$ & $\begin{array}{l}\text { Azadirachta indica } \\
\text { Magnifera indica } \\
\text { Carica papaya }\end{array}$ & Fruits & Fish \\
\hline Sericulture & Silkworm farming & $\begin{array}{l}\text { Morus alba } \\
\text { Terminalia arjuna } \\
\text { Shorea robusta } \\
\text { Ceiba pentandra }\end{array}$ & $\begin{array}{l}\text { Sorghum } \\
\text { Maize } \\
\text { Melon } \\
\text { Cocoyam }\end{array}$ & Silkworms \\
\hline Apiculture & Honey production & $\begin{array}{l}\text { Syzygum cumini } \\
\text { Eucalyptus camadulensis } \\
\text { Bee hives }\end{array}$ & $\begin{array}{l}\text { Maize } \\
\text { Sorghum } \\
\text { Millet }\end{array}$ & Bee \\
\hline Community Forestry & $\begin{array}{l}\text { Roads sides or } \\
\text { canals planting of } \\
\text { trees }\end{array}$ & $\begin{array}{l}\text { Acardium occidentale } \\
\text { Eucalyptus camadulensis } \\
\text { Anacardium occidentalis }\end{array}$ & $\begin{array}{l}\text { Sorghum } \\
\text { Millet }\end{array}$ & $\begin{array}{l}\text { Cattle } \\
\text { Sheep }\end{array}$ \\
\hline $\begin{array}{l}\text { Taungya } \\
\text { Farming }\end{array}$ & $\begin{array}{l}\text { Food crops and tree } \\
\text { production }\end{array}$ & $\begin{array}{l}\text { Tectoni grandis } \\
\text { Gmelina arborea } \\
\text { Leucaena } \\
\text { Acacia auriculaifornis } \\
\text { Acacia holosoricea } \\
\text { Sesbania grandiflora }\end{array}$ & $\begin{array}{l}\text { Yams } \\
\text { Sorghum } \\
\text { Maize } \\
\text { Melon } \\
\text { Beans }\end{array}$ & $\begin{array}{l}\text { Cattle } \\
\text { Sheep } \\
\text { Goats }\end{array}$ \\
\hline Shelterbelt & Hedgrow cropping & $\begin{array}{l}\text { Eucalyptus camadulensis } \\
\text { Acacia auriculaifornis } \\
\text { Acacia holosoricea } \\
\text { Azadirachta indica } \\
\text { Senna sieniea } \\
\text { Faid herbi albida }\end{array}$ & $\begin{array}{l}\text { Watermelon } \\
\text { Sorghum } \\
\text { Millet } \\
\text { Melon }\end{array}$ & $\begin{array}{l}\text { Cattle } \\
\text { Sheep } \\
\text { Goats }\end{array}$ \\
\hline Home Garden & Homegarden & $\begin{array}{l}\text { Mangifera indica } \\
\text { Zizyphus mauritiana } \\
\text { Gmelina arborea } \\
\text { Psidium guajava } \\
\text { Ceiba pantendra } \\
\text { Cajanns cajan } \\
\text { Moringa oleifera }\end{array}$ & $\begin{array}{l}\text { Vegetables } \\
\text { Potatoes } \\
\text { Maize } \\
\text { Pawpaw } \\
\text { Pineapple }\end{array}$ & $\begin{array}{l}\text { Goats } \\
\text { Sheep } \\
\text { Goats } \\
\text { Poultry } \\
\text { Piggery }\end{array}$ \\
\hline
\end{tabular}

Table 2: Mean Score of Respondents' Benefits Derived from Agroforestry Practices in order of Ranking in Taraba State, Nigeria

\begin{tabular}{lcc}
\hline Benefits Derived & Mean Score & Ranking \\
\hline Increase in income & 2.35 & $1^{\text {st }}$ \\
Forest materials for building & 2.50 & $2^{\text {nd }}$ \\
Availability of more sources of revenue & 2.86 & $3^{\text {rd }}$ \\
Increased crop yield & 3.65 & $4^{\text {th }}$ \\
Source of medicinal plants & 3.90 & $5^{\text {th }}$ \\
Enhancement of environment & 4.20 & $6^{\text {th }}$ \\
Fodder for animals & 4.50 & $7^{\text {th }}$ \\
Use of fallow of croplands & 5.20 & $8^{\text {th }}$ \\
\hline
\end{tabular}


Table 3: Frequency Count and Percentage of Respondents' Constraints to Participate in Agroforestry Practices in Taraba State, Nigeria

\begin{tabular}{lccccc}
\hline & $\begin{array}{l}\text { Zing } \\
\text { Zone }\end{array}$ & $\begin{array}{c}\text { Wukari } \\
\text { Zone }\end{array}$ & $\begin{array}{c}\text { Gembu } \\
\text { Zone }\end{array}$ & \\
\hline Constraints & Freq. & Freq. & Freq. & $\begin{array}{c}\text { Total } \\
(\mathbf{n}=\mathbf{4 2 0})\end{array}$ & $\begin{array}{c}\text { Freq. } \\
\text { Water Shortage }\end{array}$ \\
Livestock grazing & 5 & 6 & 4 & 15 & $\begin{array}{c}\text { Total } \\
\text { percentage } \\
(\%)\end{array}$ \\
High Cost of Labour & 35 & 28 & 27 & 90 & 3.57 \\
Finance/ Capital & 46 & 33 & 30 & 109 & 21.43 \\
Pest/disease Attack & 45 & 28 & 30 & 103 & 25.95 \\
Long gestation Period & 6 & 7 & 6 & 19 & 24.52 \\
Lack of Chemicals & 4 & 4 & 2 & 10 & 4.52 \\
Climate & 2 & 2 & 1 & 5 & 2.38 \\
Insufficiency of Plant Species & 28 & 8 & 13 & 9 & 1.20 \\
Multiple response & 7 & 2 & 2 & 49 & 2.14 \\
\hline
\end{tabular}

Table 4: Pearson Product Moment Correlation Result Showing the Effects of Independent Variables (Benefits derived and constraints) on the Dependent Variable (Participation of Farmers in Agroforestry Practices)

\begin{tabular}{lcccc}
\hline Variables & $\mathrm{N}$ & $\mathbf{r}$ & $\mathrm{P}$ Value & Decision \\
\hline Benefits Derived & 420 & $0.310^{*}$ & 0.000 & $\mathrm{~S}$ \\
Constraints & 420 & $0.810^{*}$ & 0.000 & $\mathrm{~S}$ \\
\hline
\end{tabular}

${ }^{*}$ Significant at $\mathrm{P}<0.05 \quad \mathrm{~S}=$ Significant, NS= Not Significant

\section{CONCLUSION}

It is evident from the findings of this study that farmers' participation was sustained due to the environmental and economic benefits of agroforestry practices. It has been shown that various determinants cutting across personal benefits, social benefits and environmental benefits contributed to farmers' participation and sustainability of agroforestry practices but constraints such as high cost of labour, finance/capital, livestock grazing and insufficiency of planting species are the major constraints faced by farmers in the study area

\section{RECOMMENDATIONS}

To build upon the success stories in the study area, and also to improve the farmers' level of participation in agroforestry practices, the following recommendations were made: i. Provision of adequate information to farmers through extension agents on the benefits of agroforestry practices, in order to enhance their level of participation.

ii. Government should help farmers through provision of soft loans, subsidy, incentives and other technical assistance in order to actively participate in agroforestry practices.

iii. Educate farmers to have their own tree nurseries such that the seedlings can be accessed easily by them.

iv. Policy makers need to be informed about the benefits of agroforestry so that they can support rural development and provide environmental services.

\section{REFERENCES}


Adelabu, S. A. (2010). Agroforestry systems in Nigeria: Review of practices and benefits. Journal of Research in Forestry, Wildlife and Environment, 5(2), 228-234.

Akinbile, L. A., Salimonu, K. K., \& Yekinni, O.T. (2007). Farmers' participation in Agroforestry practices in Ondo State, Nigeria. Research Journal of Applied Science, 2(3), 229-232.

Ajayi, O. V. (2015). An evaluation assessment of agroforestry technology practices in Ekiti State. International Journal of Forestry and Environmental Science, 5(3), 221-227

Karshie, E. A., Dagba, B. I., Shomkegh, S. A., \& Amonum, J. I. (2017). Influence of demographic factors and constraints on farmers' participation in agroforestry practices in Taraba State, Nigeria. Research Journal of Agriculture and Environmental Management, 6(3), 055-060.

King, K.F.S. (2007). The history of Agroforestry. Retrieved on 20th March, 2016 from http://www.history/lakm/agro3/forestry/pdf

Leakey, C. N. (2006). Fundamental issues in Agroforestry technologies. Ankara: Gabesther Educational Publisher.

Nair, P. K .R. (2008). Introduction to Agroforestry. Netherlands: Kluwer Academic Publisher

Sangeetha, W.C., Otzen, U. \& Mazelis, T. (2015). Constraints of adopting Agroforestry System Practices by Famers. Wagon: Wegeningen Press.

Cite this Article: Karshie EA, Ajayi OV, Gideon PK, Bulus J, Mtomga NB (2017). Edward Adyondor Karshie (PhD)*, Oluwatosin Victor Ajayi, Philip Kwakwah Gideon, Joel Bulus, Naorti Boniface Mtomga. Greener Journal of Agricultural Sciences, 7(8): 182-188, http://doi.org/10.15580/GJAS.2017.8.092417139. 